GYORGYOVICHNÉ KOLTAY ELVIRA ${ }^{1}$

\title{
TÁRSADALMI TŐKE A LAKÓPARKOK KÖZÖSSÉGEIBEN
}

Kutatási tapasztalatok a budapesti agglomeráció lakóparki civil/nonprofit szervezeteinek vizsgálatából

DOI: $10.18030 /$ SOCIO.HU.2018.3.42

\section{ABSZTRAKT}

A lakóparkokkal foglalkozó szociológiai nézőpontú írások többsége erősen kritikus szemmel figyeli a lakóparkok terjedését. Társadalmi kapcsolatokra gyakorolt negatív hatásaik központi témaként szerepelnek, az elit elzárkózásának, a polarizálódó társadalom megnyilvánulásának és a szegregáció megtestesítőinek tartják őket. A lakóparki/szomszédsági szervezetek és a társadalmi tőke kapcsolatának kutatásai ellentmondásos képet vázolnak fel: a nem produktív, nem előnyös társadalmi tőke indikátoraként szerepel a lakóparkok jelenléte a szuburbán térségekben, ugyanakkor a lakóközösségek civil szerveződései pozitív hatással is lehetnek tagjaik társadalmi életére és a lakókörnyezet életminőségére.

Jelen írásomban a budapesti agglomeráció lakóparki civil szervezeteit veszem szemügyre ebből a szempontból. Coleman és Esser társadalmi tőke felfogására alapozott kutatásom eredményei azt mutatják, hogy a hazai lakóparkok lakói közötti kapcsolatok általában véve minimálisak, ugyanakkor azokban a lakóparkokban, ahol civil/nonprofit szervezetek múködnek, a társadalmi tőke szintje magasabb. Egyes lakópark típusokban pedig a civil szervezet létrejötte is elválaszthatatlan a lakóközösségben létrejövő társadalmi tókétől. A több típusba sorolt hazai lakóparkok közül elsősorban a valódi zárt lakóparkok azok, amelyekre leginkább illenek a külföldi tapasztalatok.

Kulcsszavak: lakópark, társadalmi tőke, civil szervezetek, agglomeráció 
SOCIAL CAPITAL IN THE COMMUNITIES OF GATED COMMUNITIES

Research experiences from the non-profit organizations of gated communities in the urban agglomeration of Budapest

\section{ABSTRACT}

Most of the sociological aspect literature on residential parks is very critical of the spread of gated communities. Their negative effects on social relations are a central topic, as it is believed that they help the closure of the elite, the polarization of society and embody segregation. Research into the relationship between gated communities/neighbourhood organizations and social capital reveals a contradictory situation: The presence of gated communities in suburban areas is an indicator of non-productive and non-beneficial social capital, while at the same time community organizations can have a positive impact on the social life of their members and on the quality of life of those living in the residential environment. In this paper I examine the civil organizations of the gated communities of the agglomeration in Budapest, from these points of view. Based on Coleman's and Esser's conception of social capital, I analyze the impacts on social capital of the civil/ non-profit organizations and the residential communities of gated communities. My results show that the relationships between residents of gated communities are generally minimal, while at the same time, in gated communities where a civil/non-profit organization operates, a higher level of social capital is manifested. In many cases, the foundation of the NGOs depends on the social capital of the community. Among the different types of gated communities in Hungary, closed gated communities fit most readily into the international typology.

Keywords: gated community, social capital, civil society, agglomeration 


\title{
TÁRSADALMI TŐKE A LAKÓPARKOK KÖZÖSSÉGEIBEN
}

\author{
Kutatási tapasztalatok \\ a budapesti agglomeráció lakóparki civil/nonprofit szervezeteinek vizsgálatából²
}

Az 1980-as évektől külföldön egyre inkább terjedő, amerikai mintát követő lakóparki életforma hazánkban az 1990-es években jelent meg. Terjedésének mértéke és lakószámának alakulása igen érzékenynek bizonyult a mindenkori gazdasági és társadalmi környezetre. A lakástámogatásoknak és az akkori divatoknak köszönhetően a 2000-es évek elején számuk robbanásszerűen növekedett, melyet szinte teljesen megtört az évtized végén jelentkező, az ingatlanpiacra különösen is ható gazdasági válság (Bajmóczy 2014, Schuchmann 2015 : 332). Különösen a szuburbanizációs lakóparkok voltak azok, melyek épülése szinte teljesen megállt, sőt lakóik fővárosba való visszaköltözése is megindult. Az utóbbi évek kedvezőbb ingatlanpiaci helyzete és a lakástámogatási rendszer változása azonban ismét új trendeket hoztak (KSH 2016: 9). Így a lakópark-építések felélénkülése, az életforma újbóli divatja ismét aktualitássá teszi kutatásukat. Immár két évtizedes múltjuk és a fejlődésükre jellemző ellentmondásos folyamatok indokolttá teszik a longitudinális, több szempontú kutatásokat.

Jelen írásomban a lakóparkokra, illetve kiemelten a lakóparkokban múködő civil/nonprofit ${ }^{3}$ szervezetekre jellemző társadalmi tőkét elemzem. Megállapításaimat a budapesti agglomeráció lakóparki civil/nonprofit szervezeteiről 2009-ben, majd 2016-2017-ben, részben longitudinálisan végzett empirikus adatgyűjtésemre alapozom. Habár az említett kutatás fókuszában nem a lakóparkok társadalmi tőkéje állt, az ezzel kapcsolatos eredményeket mégis érdemes önállóan is bemutatni. Három fő kutatási kérdést fogalmaztam meg:

1. A lakópark a társadalmi tőke koncentrációjának potenciális színhelye-e?

2. Példa lehet-e a lakópark a negatív, összekötő („,bonding”) típusú társadalmi tőkére?

3. Tekinthetők a lakóparki civil/nonprofit szervezetek a társadalmi tőke „termékeinek” és „újratermelőinek”?

A társadalmi tőke elméletek közül elsősorban Coleman (1994) funkcionális szempontú értelmezéséből és az Esser (2008) által megkülönböztetett, kapcsolati és hálózati tőke típusokból indulok ki.

Társadalmi tőke értelmezésében Coleman megmarad az egyének, illetve kisebb csoportokra vonatkozó társadalmi tőkefogalom szintjén, ugyanakkor kiemeli annak közjószág jellegét. A társadalmi tőke, mivel a társadalmi struktúrában rejlik, nem csak azokra hat, akik létrehozzák, hanem az adott struktúra minden tagjára. Ez a

2 Köszönettel tartozom a Központi Statisztikai Hivatal munkatársainak, akik rendelkezésemre bocsátották a budapesti agglomeráció lakóparkjaira, illetve az általam vizsgált lakóparkokra vonatkozó népszámlási adatokat.

3 A civil/nonprofit elnevezés alapvetően a hazai nonprofit szektor duális jellege miatt terjedt el (Bartal 2005: 304). Tanulmányomban ez a szóhasználat utal arra, hogy a lakóparki szervezetekben is felfedezhető egyfajta kettősség, hiszen egy részük alulról szerveződő „civil” szervezet. Uugyanakkor a lakóparkok fenntartását végző nonprofit kft.-ket jellemzően az üzemeltetés céljára hozza létre a lakóparkot létrehozó befektető, az alulról szerveződő, önkéntes jelleg esetükben kevésbé domináns, ellenben a „nonprofit” kifejezés jól leírja múködésmódjukat. 
jellegzetessége kollektív cselekvési és potyautas-problémákat is felvet. Éppen ezért lehetséges, hogy bár a társadalmi tőke a kapcsolatokba történő tudatos egyéni befektetésből is létrejöhet, közjószág jellegéből adódóan sok esetben más célokra irányuló tevékenységek mellékterméke (Coleman 1994: 115). Esser értelmezésében a kapcsolati tőke az, amelyben az egyéni nézőpont dominál, személyes erőforrás és szándékos személyes beruházástól függ. Három altípusa a pozicionális, a bizalom- és a kötelezettségtőke. A hálózati tőke ezzel szemben nem az egyének birtoka, hanem a köztük lévő viszonyokban létezik, és nem is közvetlenül az egyéni beruházásoktól függ. Közjószág, mivel előnyeiből nem zárhatók ki azok, akik nem járultak hozzá, a hálózat vagy csoport minden tagja részesedik belőle. Altípusai a hálózatkontroll, a hálózatbizalom és a hálózatmorál (Kisfalusi 2013: 89-95).

Coleman általánosságban megfogalmazott állitását Esser a hálózati tőkére szúkíti, és csak ezt a társadalmi tőketípust tartja más cselekvések melléktermékének. Így tehát „mikroszinten a kapcsolati tőkébe történő egyéni beruházások és döntések eredményeképpen makroszinten kialakulnak a hálózati tőke különböző típusai. A hálózati töke kialakulása azután visszahat az egyéni cselekvőkre, elösegítve a kapcsolati tőke hatékonyabb müködését." (Kisfalusi 2013: 96)

Amikor a lakóparkok és civil szervezeteik társadalmi tőkéjét vizsgálom Esser nyomán, tulajdonképpen a lakók közösségének hálózati tőkéjét vizsgálom. Annak ellenére, hogy a való életben nem különíthető el egymástól annyira a kapcsolati és a hálózati tôke, elemzésem fókusza a lakók között létrejövő hálózat és ennek tulajdonságai lesznek. A hálózati tőke az, amely különböző típusú lehet aszerint, hogy milyen hatással van a kapcsolatokra és a cselekvésre (Lin 2008). Putnam (2000) nyomán, aki összekötő (vagy kizáró), illetve áthidaló (vagy befogadó) társadalmi tőkéről beszél, Woolcook és szerzőtársai három társadalmi tőketípust különböztetnek meg. Az összetartó társadalmi tóke (bonding social capital) általában személyközi kapcsolatokra és homogén csoportokra jellemző, az egyének közötti sűrű és erős kötésekkel. Az összekötő társadalmi tőke (bridging social capital) csoporthatárokon átnyúló kapcsolatokat jelent, mely segíti a különböző társadalmi csoportok közti integrációt. Ennek vertikális változatát összekapcsoló társadalmi tőke (linking social capital) elnevezéssel különítik el a másik két típustól. (Woolcock-Narayan 2000, Woolcock 1998, Szreter-Woolcock 2004). Habár ezek a típusok és a hozzájuk kapcsolt jellemzők általában a társadalmi tőkére vonatkoznak, Lin (2008) gondolatmenete alapján, aki ezeket a hálózat tulajdonságának tartja, én a hálózati tőkére vonatkoztatom. Ezek közül a tőketípusok közül elsősorban az összetartó (bonding) típus az, amelyet negatív hatásúnak szoktak tartani az egész társadalomra, de bizonyos esetekben az egyénre nézve is. Ennek oka, hogy a befelé sűrű és erős kötések hiába segítik a csoport összetartást és sikerességet, korlátozhatják az egyéni szabadságot, és elszigetelhetik egymástól a különböző társadalmi csoportokat. Az azonban, hogy egy társadalmi közeg mennyire nyitott vagy zárt, hálózati tőkéjét negatív vagy pozitiv hatásúnak bélyegezzük, általában nem írható le csupán egyetlen társadalmi tőketípussal. Megyesi (2015) kutatása megmutatta, hogy a különböző tőketípusok jelenlétének aránya a meghatározó abban, hogy a társadalmi tőke, így azon belül a hálózati tőke pozitív vagy negatív hatásokkal jár.

Ebben az írásban tehát a társadalmi tőketípusok közül elsősorban a hálózati tőke szerepe kerül előtérbe a vizsgált civil szervezetek életében. Különböző típusainak jelenléte - a lakópark társadalmi tôkéjével kapcsolatos kritikai hangok ismeretében - különösen is fontos elemzési szempont.

4 Esser munkájának részletes ismertetése és a kritikai észrevételek bővebben Kisfalusi Dorottya 2013-ban megjelent cikkében olvashatóak. 


\section{A LAKÓPARKOK ÉS A TÁRSADALMI TŐKE KAPCSOLATA}

A nemzetközi szakirodalomban a lakópark (többnyire „gated community” elnevezéssel) olyan zárt lakóövezetet jelent, ahol korlátozzák, illetve ellenőrzik a lakóterületre való belépést (pl. sorompóval, térfigyelő kamerákkal, biztonsági őrrel). A lakók közös javait és a közösen használt szolgáltatásokat a lakók szerződéses megbízása alapján egy közösségi önigazgatási feladatokat ellátó szervezet gondozza és biztosítja (Cséfalvay 2008: 13). A zárt lakóparkok a klubok (Buchanan 1965) valamennyi ismérvével rendelkeznek:

- Helyi közjavakat (pl. utakat, játszóteret) hoznak létre és müködtetnek.

- A közjavak finanszírozása és használata a tagok között megosztott, amit a közös költség biztosít.

- Képesek kizárni a potyautasokat. A biztonság és a közös javak védelme mellett ezt szolgálja a zártság.

- A helyi közjavak terén versenyeznek a települési önkormányzatokkal. A javakat hatékonyabban, gazdaságosabban, és sok esetben magasabb színvonalon állítják elő.

- Taglétszámuk korlátozott.

- Önkéntes alapon szerveződnek: a leendő lakók maguk döntik el, hogy hol akarnak ingatlant vásárolni.

- Társadalmi összetételük meglehetősen homogén, amely következik az előző pontból. Adott lakóparkot árai és kínált szolgáltatásai okán, közel azonos anyagi helyzetú és preferenciájú vásárlók választják.

A klubszerű múködés és így a helyi közjavak hatékony előállítása tehát a közgazdaságtani magyarázata lakóparkok létrejöttének. Az ilyen értelemben vett lakóparkokkal kapcsolatos szociológiai nézőpontú írások ugyanakkor meglehetősen kritikusak (pl. Glasze 2005, Low 2003, Atkinson-Blandy 2005). Jellemzően (felső)középosztályhoz tartozó társadalmi csoportok lakhelyeként az elit elzárkózásának (Dhavale-Sanchez-Lang 2005), a polarizálódó társadalom megnyilvánulásának és a szegregáció megtestesítőinek tartják őket (McKenzie 2003). Vizsgálatok azt mutatják, hogy a lakóparkban élőknek kevés kapcsolata van a környező település lakosságával, gépkocsihasználatra alapozott életmódjuk révén alig érintkeznek a sajátjukon kívüli társadalmi csoportokkal (Hegedüs 2007). Egyes szerzők szerint még az új lakók számára esetleg vonzó lakóparkon belüli közösségi élet sem valósul meg, a lakók közti kapcsolatok minimálisak (Sanchez-Lang-Dhavale 2005). A hivatkozott kutatásokban szereplő lakóparkok jómódban élő lakóinak nincs szükségük igazán egymásra, kapcsolataik nem füzik őket a szomszédsághoz, közös ügyeik intézését a közösségi szervezet végzi, érintkezésük csak ennek ügyeiben szükséges.

Kifejezetten a társadalmi tőke és a lakóparkok kapcsolatával foglalkozó kutatásokra is jellemző a kritikai hang. Debertin és Goetz (2013: 9) írásában a nem produktív, nem előnyös társadalmi tőke indikátoraként szerepel a lakóparkok jelenléte a szuburbán térségekben. Wilson (1997: 747) a külvárosi társadalom negatív társadalmi tőkéjéről beszél a zárt lakóközösségek esetén. Lang és Danielson (1997) azonban már árnyalják ezt a képet, és úgy látják, hogy ennél azért összetettebbek a társadalmi kapcsolatok a lakóparkokban. Úgy vélik, lehet, hogy a kívül élőktől elszigeteltek, de befelé összetartó hatása van ezeknek a zárt közösségeknek, és a szomszédok könnyebben összefognak javaik és életterük közös védelmére, fejlesztésére.

Az USA szomszédsági szervezeteit és a társadalmi tőke kapcsolatát vizsgáló kutatás (Ruef-Kwon 2016) eredményei azt mutatták, hogy ha a szomszédsági szervezetek egyszerūen csak a lakókörnyezet értékének nö- 
velésére jönnek létre, akkor nem lesznek hatékonyak a szomszédságok közötti áthidaló társadalmi tőke növelésére, sőt erősítik a bizalmatlanságot. Ebben az esetben olyan vásárlók számára lesznek vonzóak, akik az ingatlanbefektetésük megtérülését várják tőlük, valamint azt, hogy a szomszédsági szervezetben való részvétel révén nő a passzív társadalmi tôkéjük. Ha azonban nem csak a javak fenntartása és növelése a cél, akkor ezek a szervezetek növelik a lakók bizalmát a környezetük felé. Különösen a bérlők esetében korrelált a szervezeti tagság a szomszédságba vetett bizalommal, az együttmúködési készséggel, de még a csoporton kívüli és a kisebbségek felé érzett magasabb bizalommal is. Ruef és Kwon kutatásuk konklúziójában megállapítják, hogy az USA-ban a szomszédsági szervezetek számának és tagságának elmúlt évtizedekben tapasztalt hatalmas növekedése éppen ellentétes a Putnam (2000) által leírt folyamattal, mely más társas tevékenységek drámai csökkenését mutatja. Ennek a trendnek a következményei az USA-ban szerintük kétértelmúek. Egyrészt ezek a szervezetek a korábbi történelmi mintát folytatva erősíthetik a társadalmi polarizációt és a szegregációt. Ugyanakkor a szomszédsági szerepvállalás és a közösségépítés eszközeiként számbeli növekedésük akár ellensúlyozhatja is a társadalmi tőke más önkéntes szervezetek esetében tapasztalható erózióját. Így tehát a társadalmi tőkére gyakorolt hatásuk a közösség lakóinak érdekeitől és az egyesületek állami szabályozásától függ. (Ruef-Kwon 2016: 182-183)

A lakóparkokhoz kapcsolódó külföldi társadalmi tőke-vizsgálatok három fő megállapítása, hogy a lakóparkok társadalmi tőkéje alacsony, és ha fel is fedezhető a társadalmi tőke valamilyen fajtája ezekben a közösségekben, akkor annak negatív hatásai dominálnak. Végezetül pedig a lakóparki közösségek körében a javak fenntartásához kapcsolódó érdekek az összetartó („,bonding”) jellegű kapcsolatok dominanciájának kedveznek.

Kérdés, hogy mindezen nemzetközi tapasztalatok fényében - a bevezetésben említett három kutatási kérdés mentén áttekintve -, mit mondhatunk a hazai lakóparkokról és civil/nonprofit szervezetekről.

\section{MÓDSZEREK}

Mivel hazánkban a lakópark fogalomnak nincs egységesen elfogadott kritériumrendszere, mást ért alatta a Központi Statisztikai Hivatal (KSH), a hétköznapi szóhasználat és a szakirodalom, ${ }^{5}$ a vizsgálati kör meghatározásához a Cséfalvay (2008) által leírt, fentebb ismertetett nemzetközi lakópark-definícióból indultam ki.

Aszerint, hogy mennyire felelnek meg ennek a meghatározásnak, öt típusba soroltam a hazai, lakóparknak nevezett beruházásokat (Koltay 2010):

- A teljesen zárt lakóparkok csoportjába soroltam a nemzetközi kritériumrendszernek teljes mértékben megfelelő, fallal vagy kerítéssel is körülvett lakóparkokat, melyek közös területei magántulajdonban vannak, és a közös javak és szolgáltatások viszonylag széles körével rendelkeznek.

- Az inkább zárt lakóparkok csoportja köztes kategória. Azokat a lakóparkokat soroltam ide, melyek a zárt lakóparkoktól csak egy-egy definíciós kritériumban térnek el. Pl. zárt lakópark, de közös területei önkormányzati tulajdonban vannak, vagy magántulajdon és elvileg nem mehet be idegen, határát mégsem őrzik és nincs lekerítve.

5 A KSH 2003 óta szerepelteti külön kategóriaként a lakóparkokat és „egy helyrajzi számon nyilvántartott telken elhelyezkedő, egységes épitészeti arculattal kialakitott, többlakásos lakóépületekböl álló épületegyüttest" (KSH 2007)

A hétköznapi szóhasználatban és az ingatlanhirdetésekben általában az újonnan, telepszerúen épített ingatlancsoportokat nevezik lakóparknak, egyéb kritérium ritkán merül fel. 
- A közepesen zárt lakóparkok csoportjába azon beruházások kerültek, melyek területileg elkülönülnek a településtől, ahová tartoznak, és általában valamilyen módon, jellemzően térfigyelő kamerával, kontrollálják is a belépőket. A közös szolgáltatások minimálisak, de a lakók rendelkeznek közös tulajdonnal.

- Az inkább nyílt lakóparkok kategóriája szintén köztes kategória. Ezek az ingatlancsoportok a nyílt lakóparkok csoportjához állnak a legközelebb, ugyanakkor elhelyezkedésükből adódóan nem a település szerves részei, ez pedig kihatással van az ott élők életmódjára és a település életébe való bekapcsolódásukra. Közös javaik és szolgáltatásaik minimálisak.

- A teljesen nyílt lakóparkok valójában csak nevükben lakóparkok, szerves részei az adott településnek, és attól egyáltalán nem különülnek el. A belépést nem kontrollálják, és jellemzően saját belső szolgáltatásokkal sem rendelkeznek. Amennyiben lenne a lakóparkokra vonatkozó jogi szabályozás, feltételezhetően nem is lehetne lakóparknak nevezni őket.

A budapesti agglomeráció településeire (Budapestet nem számítva) szúkített munkámban, elsősorban a lakóparki civil szervezetek múködését és lakóparkban betöltött szerepét kutattam. E vizsgálati területen önkormányzati adatok és saját adatgyüjtésem alapján 149 olyan ingatlanberuházást találtam (2016. évi adat), amelyet az érintett önkormányzat vagy a befektető és az ott élők lakóparknak hívnak. Azt tapasztaltam, hogy ezekben a lakóparkokban a lakók szerveződésének három, külső szemlélő számára is érzékelhető fokozata figyelhető meg:

- Az első esetben nincs külső jele a társadalmi kapcsolatoknak, amelyek valószínúleg nem terjednek túl a szokásos szomszédsági kapcsolatokon.

- A második esetben már megindul egyfajta hálózatosodás, tágabb informális közösségi kapcsolat, melynek jele lehet a lakóparkhoz kötődő online felület, korábban jellemzően levelezőlisták, fórumok, mostanában főként zárt Facebook-csoportok.

- A harmadik - kutatásom célcsoportját jelentő - esetben formális szervezet is kötődik az adott lakóparki közösséghez (nem kizárva egyidejúleg az informális társadalmi fórumokat.)

A fenti vizsgálati csoportban a 149 lakóparkból összesen 38-hoz kötődően találtam működő Facebookcsoportot és 18 lakóparkban civil/nonprofit szervezet (is), más-más arányban a lakóparkok különböző típusaiban. A kvalitatív és kvantitatív adatfelvételbe ez az utóbbi, civil/nonprofit szervezettel is rendelkező csoport jutott, melyek közül végül 17 lakópark került a mintába, ahol összesen 19 szervezet múködött.

Az adatfelvétel kvalitatív fázisban strukturált interjúkat készítettem a vizsgálatba került lakóparki szervezetek vezetőivel, illetve az érintett önkormányzatok képviselőivel. Mivel az önkormányzatok közül három (Fót, Kistarcsa és Nagytarcsa) megtagadta a válaszadást, a 17 szervezeti mellett 11 önkormányzati interjú készült el. Ezen kívül két esetben (Magdolna-völgy és Fenyő lakóparkok), ahol a lakóparki szervezet jelenlegi helyzete indokolta, a lakóközösség életében aktív szerepet vállaló egy-egy lakóparki lakossal is készült interjú. Így végül a kvalitatív kutatási fázis eredményei összesen 30 strukturált interjún alapulnak. ${ }^{6}$ 
Az adatfelvétel kvantitatív fázisában a lakók körében végeztem kérdőíves adatfelvételt.7 Az online kérdőív 2016 tavaszától 2017 tavaszáig volt elérhető a kérdezettek számára, amelyre - mivel a lakóparkok lakói rendkívül nehezen elérhető célcsoportnak és kritikusan gyenge válaszadói hajlandóságúnak bizonyultak - több módon is felhívtam a célcsoport figyelmét (belső levelező listák, online csoportok, illetve bizonyos esetekben postai levél is). Ennek eredményeképpen összesen 162 értékelhető kitöltés érkezett. ${ }^{8}$ Habár teljes lekérdezésre törekedtem, mégsem volt mindenkinek egyforma esélye a mintába kerülésre, így a kapott eredmények nem tekinthetők reprezentatívnak, inkább kiegészítései, illetve korlátozott mértékben, de kontrolljai az interjúkon elhangzottaknak. A kvalitatív és kvantitatív adatfelvétel során kapott adatokat kiegészítettem KSH 2011. évi népszámlálásának vonatkozó adataival. ${ }^{9}$

Az elemzés megkezdése előtt a kapott adatok és információk birtokában soroltam be a vizsgált lakóparkokat a korábbi részekben említett lakópark tipológiába, mely az elemzés egyik alapszempontját képezte. Közülük mindössze 4 felelt meg a zárt lakóparkra vonatkozó kritériumrendszernek (Fót: Fótliget, Mogyoród: Szent Jakab Parkfalu, Piliscsaba: Magdolna-völgy és Dunabogdány: Bogonháti Major), két lakóparkot soroltam az inkább zárt (Budajenő: Hilltop I-II. és Délegyháza: Robinson Park), öt lakóparkot a közepesen zárt (Dunavarsány: Naprózsa Lakópark, Piliscsaba: Csabagyöngye és Garancstető, Páty: Páty Zsámbéki-kanyar lakópark, valamint Üröm: Péterhegyi-Rókahegyi Lakópark), hármat az inkább nyílt (Dunakeszi: Fenyő Lakópark és Alagliget, Nagytarcsa: Füzesliget) és szintén három lakóparkot (Biatorbágy: Zöld Sziget Lakópark, Kistarcsa: Torony Lakópark és Dunaharaszti. Nádor Lakópark) a teljesen nyitott lakóparkok közé. ${ }^{10}$

\section{EREDMÉNYEK}

Az első fontos megállapítás a vizsgált hazai lakóparkokra vonatkozóan a lakóik speciális társadalmi helyzetéből fakad. Esetükben is igaznak bizonyult a lakóparkokra vonatkozó azon kitétel, miszerint ez a lakóforma jellemzően a magas társadalmi státuszú csoportok lakóhelye, mely jellemzően magas anyagi, kulturális és magas társadalmi tőkét is eredményez. Magas anyagi tőkére utal a lakóparkok nívója, az ingatlanok értéke (a zárt lakóparkoktól a nyíltak felé haladva csökkennek az ingatlan-árak) és a terepszemlén tapasztaltak (pl. a lakóparkokba behajtó gépkocsik árfekvése, a fogyasztási szokásokra utaló egyéb jelek), valamint az is, hogy a közhasznú státusszal rendelkező lakóparki szervezeteknek kimagasló az egy felajánlóra jutó SZJA 1\%-os bevételük (Koltay 2010). Anyagi, de egyben kulturális tőkéjük magas szintjét jelzik az iskolai végzettségre és a foglalkozásra vonatkozó adatok, melyek 12 vizsgált lakópark esetében álltak rendelkezésre. A 2011. évi népszámlás adatai alapján a 12 lakópark 15 évnél idősebb lakosságának 38,4\%-a rendelkezik felsőfokú végzettséggel, 30,0\%-a érettségivel, 9,8\%-a szakmai középfokú végzettséggel és 13,4\%-a 8 általános, vagy annál kevesebb iskolai végzetséggel.

7 2009-ben az akkori vizsgálati körből összesen 72 kérdőívre kapott választ kaptam, mely akkor kb. 13\%-os válaszadói arányt jelentett (Koltay 2010).

8 A 2011. évi népszámlálás háztartásokra vonatkozó adatai alapján, melyet a KSH bocsátott rendelkezésemre, ez a kitöltési arány megközelítőleg 6,5\%-os válaszadói hajlandóságot jelent a vizsgált csoportban.

9 Sajnos az adatvédelmi szabályok, illetve a nyílt lakóparkok nehéz lehatárolhatósága miatt a kikért adatbázis csak részben tartalmazta a vizsgálatba került lakóparkokra vonatkozó népszámlálási adatokat. A különböző kutatási fázisokból nyert információkat még kiegészítettem egyéni adatgyűjtéssel is, melynek módszerei a terepszemle, vonatkozó sajtó, internetes hirdetése és fórumok áttekintése volt.

$10 \mathrm{Az}$ adatfelvétellel kapcsolatos további, részletes adatokat tartalmaz a mellékletben található táblázat. 
Ugyanakkor a közepesen zárt, inkább zárt és zárt lakóparkok között több esetben is 50\%-ot meghaladó a diplomával rendelkező, vezető beosztásban dolgozó, szellemi foglalkozásúak aránya. ${ }^{11} \mathrm{~A}$ magas társadalmi státusz magasabb társadalmi tőkével jár együtt (Hajdu-Megyesi 2017: 161). Ezért az interjúk és korábbi kutatásaim alapján azt feltételezem, hogy a vizsgált lakóparkok lakói magas társadalmi tőkével is rendelkező egyének. ${ }^{12}$

Bourdieu (1998) nyomán tudjuk, hogy az egyén társadalmi tókéjének nagysága egyrészt függ kapcsolatainak kiterjedtségétől, másrészt azoknak a személyeknek az erőforrásaitól, akikkel kapcsolatban áll. Ugyanez igaz az általam vizsgált civil/nonprofit szervezetekre, amelyeknek tókéje függ egyrészt az általuk birtokolt hálózati tőke nagyságától, ugyanakkor a hálózatot alkotó személyek erőforrásaitól is. A lakókra vonatkozó, ismertetett adatok alapján feltételezem, hogy a lakóparkokban a különböző tőkefajták koncentráltan vannak jelen, így a potenciálisan rendelkezésre álló társadalmi tőke mértéke is igen magas. Ugyanakkor csak akkor válik valóban erőforrássá, ha az egyének kapcsolatba lépnek egymással, és a szervezetek mozgósítani tudják a rendelkezésre álló társadalmi tőkét. Ahogy az alábbi idézetek is mutatják, ha erős a hálózati tőke, az jelentős erőforrást biztosíthat közös ügyeik intézéséhez, szervezetük múködtetéséhez:

„.... odamentem emberekhez, akikröl tudtam, hogy hozzáértök. HR-es voltam. Legyen könyvelö, jogász, férfi, aktivista, szervezö, összeraktam egy csapatot stb. Akkor indult az egyik srác a helyi választásokon, és akkor őt kértük meg elnöknek, mert akkor ő viszi-hozza a híreket az önkormányzattól." (egyesület 1 , alapító)

„Vannak olyan emberek, akikre mindig lehet számitani, pl. jogász, könyvelö, apeh ellenőr stb." (egyesület 2, elnökségi tag)

"... egy tv-nél salesként dolgozó lakó 170 ezer Ft értékben gyüjtött össze adományokat a tombolához..." (egyesület 2, elnökségi tag)

A lakók közti hálózati tőkére és annak milyenségére a lakóparkokban tapasztalt közösségi kapcsolatokból, illetve a szervezeteknek a környező társadalomban elfoglalt helyből következtettem. A különböző lakópark típusokban a közösségi kapcsolatok és a lakók szerveződésének más-más mintázatait figyeltem meg, melyek összefüggenek a szervezetek által betöltött, vagy a tőlük elvárt feladatokkal, funkciókkal, sőt magának a szervezetnek a létével is. Vizsgálatom során három plusz egy ilyen funkciót különítettem el. Ezek az önigazgatás és területfejlesztés, az érdekvédelem, a közösségépítés, valamint a tágabb társadalmi közegbe, általában az adott település életébe való integráció segítése. Ezek közül a közösségépítési feladatok szolgálják közvetlenül a lakóparkon belüli társadalmi tőke erősödését, az integrációval kapcsolatos tevékenységek pedig a tágabb társadalmi közeg felé kialakuló kapcsolatokat. A különböző lakóparki szervezetek múködésében ezek a funkciók más-más arányban vannak jelen:

Zárt lakóparkok esetében a közös javak (pl. utak, világítás, parkok, játszóterek) fenntartása és a szolgáltatások (pl. gondnok, biztonsági őr) biztosítása, mely az önigazgatási funkcióhoz kapcsolódik, feltételez valamilyen szervezeti múködést, így a zárt lakóparkokban mindenképpen múködik valamilyen fenntartó szervezet. A budapesti agglomerációban található négy zárt lakópark közül ezeket az önigazgatási feladatokat két esetben

$11 \mathrm{Az}$ adatok a KSH által rendelkezésre bocsátott adatokon alapulnak.

12 Ennek igazolásához azonban további kvantitatív adatok lennének szükségesek. 
nonprofit kft., egy esetben egy cég, a negyedik, legkevesebb lakóegységgel rendelkező lakópark esetében pedig a lakók egyesülete végzi. Ezek a szervezetek az amerikai példákhoz hasonlóan elsősorban a javak védelmében és fejlesztésére jöttek létre, a lakók közötti kapcsolatok erősödését csak közvetve, maximum a közös ügyekben való részvétel erejéig fejlesztik. Interjúalanyaim általános tapasztalata a közösségi kapcsolatok hiánya és a lakók közös ügyek iránti motiválatlansága.

„Ez azért egy elég elzárt, elszigetelt lakópark és az itt élök éppen ezért választották ezt a helyet, nem annyira közösségi emberek, nincs igényük ilyesmire. Szinte mindenki Budapesten dolgozik, kevés időt töltenek együtt." (egyesület 3 , elnök)

„... sok mindent lehetne is csinálni, de nincs hozzá közösségi erő." (egyesület 3, elnök)

Ennek ellenére mind a négy zárt lakóparkban múködik a lakók (egy aktívabb csoportja) által alapított és múködtetett egyesület is. Ezek létrehozásának motivációja jellemzően valamilyen közös érdeksérelemhez, fenntartási problémához kötődik, ugyanakkor tevékenységükben megjelenik a közösségépítés szándéka, illetve esetenként eltérő mértékben, de a település életébe való a bekapcsolódás, a helyi önkormányzattal való kapcsolattartás is.

„Időről időre vannak ilyen ügyek, ami miatt össze kell fogni, ha joghátrány miatt fenyeget bennünket, akkor összehoz minket. Dacára annak, hogy alvó településrész, azért van igény arra, hogy egymást ismerjük. Ezért vannak közösségi rendezvények: majális vagy juniális, volt korábban karácsonyi rendezvény." (egyesület 4, elnök)

A helyi önkormányzatokkal való kapcsolatokban azonban több esetben megjelennek akár súlyos konfliktusok is, de mindenképpen egyfajta távolságtartás a jellemző.

"Az önkormányzat úgy gondolkodik, hogy ha mi majd támogatjuk a falut, akkor majd ök is minket." (egyesület 3, elnök)

„A falu azzal érvel egyébként, ami szintén értheto", hogy a faluban is sok minden nincs itt sem, meg ott sem, majd ha az meglesz, akkor foglalkozik velünk. Önállóan kell vinni a dolgainkat." (egyesület 3, elnök)

„A közösségi élet szervezése önkormányzati feladat, de maga az érdekközösség is különszakította [a lakóparkot]. Mert pl. az áramot stb. sem mi fizetjük a lakóparkban, ök meg nem akarják közúttá tenni az útjaikat. Ez kényes probléma." (önkormányzati interjú)

„Önkormányzati szinten jó ez így, nincs velük gond, de emberi és politikai oldalról lenne jó közelebb kerülni hozzájuk." (önkormányzati interjú)

"Korábban velük is érdekfeszültség, de a mostani testülettel nagyon jó a kapcsolat. Van egy intenzív élö kapcsolat, így nagyon jól tudunk együttmüködni." (egyesület 4, elnök)

Az inkább zárt lakóparkokban bizonyos feladatokat az önkormányzat is elvégez, közös javaik gondozása mégis hivatalos jogi személy meglétét teszi szükségessé. Az ebbe a kategóriába sorolt két lakóövezetben egyesületek múködnek. Elsődleges feladatuk a terület gondozása, fejlesztése és fenntartása, ezt egészíti ki a közösségi programok szervezése, és adott esetben a lakóparki közösség érdekeinek képviselete. Mindkét lakóparkra jellemző bizonyos szintű közösségiség, illetve a szervezetek révén a település életébe is némileg bekapcsolódnak, de az interjúk alapján szoros kapcsolatokról sem a lakóparkon belül, sem kívül nem beszélhetünk. 
A közepesen zárt és az inkább nyillt, valamint a nyillt lakóparkok esetében a fenntartást az önkormányzat végzi, közös területeik közterületek, akárcsak a település többi része, éppen ezért külön önigazgatási, fenntartást végző szervezetre nincs szükség. Ez lehet az oka annak, hogy a budapesti agglomerációban talált, ezekbe a kategóriákba tartozó, lakóparknak nevezett legtöbb ingatlancsoport esetében bejegyzett civil szervezetet nem találtam. Amennyiben közös ügyeik megkívánják, az itt élők inkább online fórumon érintkeznek egymással, bár még ez sem mindenhol jellemző. Azokban a lakóparkokban, ahol mégis múködik civil szervezet, a szervezetalapítás többféle motivációját találtam. Első és legerősebb motivációs tényezőnek valamilyen közös érdeksérelem bizonyult (pl. befektető eltűnése miatt kialakult tisztázatlan jogi helyzetek, közelbe tervezett nagyszabású beruházás elleni fellépés, rossz kivitelezői munka). Ezek olyan közös problémák, melyek a lakosságot gyors és hatékony összefogásra ösztönözték.

„... az önkormányzatnak voltak olyan fejlesztési és beépitési elképzelései, amiket szerettünk volna megakadályozni. Valami ellen alakult." (egyesület 5, elnök)

„... beszakadtak az utak (...), a vállalkozó tulajdonában voltak (...), nem volt, aki megcsinálja” (egyesület 2, elnökségi tag)

Céljaik eléréséhez a leghatékonyabb módnak civil szervezet, legtöbb esetben egyesület alapítását találták. „Van egy forma, aminek a keretében felléphetünk, mert ha bármi volt, akkor mint egyesület nagyobb hangunk van, mint egyesével." (egyesület 4, elnökségi tag)

Egy másik lehetséges és tipikus mozgatórugó - amely egyszerre is jelen lehet az előzővel - valamilyen közös lakóparki fejlesztés létrehozása (pl. játszótér, park).

„Itt nem volt járda a faluba,, itt nem lehetett semmit csinálni. Közös volt a cél, hogy legyen egy játszótér, hogy legyen mit ott csinálni. Már az iskolásokat is ide hozzák játszani a faluból. Azóta elértük azt is, hogy legyen híd a patak felett a falu felé és lett bicikliút és közvilágítás a lakóparkig, falutábla idáig, így tudnak a gyerekek iskolába járni egyedül. Csinált az önkormányzat buszmegállókat, fedettet, ami eddig nem volt. Hirdetőtábláink is vannak. Szépen fejlődik a lakópark." (egyesület 6, elnök)

Találtam olyan lakóparki szervezetet is, amely eredendően a lakók közösségi életének szervezésére jött létre. Ez utóbbi azonban a legritkább eset. Azt tapasztaltam, hogy a közösségépítés és az integrációs funkciók, melyek a többi funkcióhoz képest közvetlenebbül kapcsolódnak a lakóközösség társadalmi tőkéjének mértékéhez, a szervezetek alapításakor még nincsenek annyira markánsan jelen, vagy csak mellékes tevékenységnek számítanak. Az idő előrehaladtával és jobb esetben az alapítási cél elérésével egyre inkább előtérbe kerülnek.

„.... sikerült, hogy nem csak szomszédok legyünk, hanem figyelünk egymásra." (egyesület 7, elnök)

A közösségépítést olyan tevékenységek szolgálják, mint a honlap és a levelezőrendszer múködtetése, vagy különböző közösségi programok szervezése (pl. közös szemétszedés, Mikulás és gyereknapi rendezvények).

Integrációs funkció alatt azokat a tevékenységeket értem, melyek összekötik a lakópark lakóit és az anyatelepülést egymással. Ilyenek az önkormányzattal és más helyi civil szervezetekkel való kapcsolattartás, részvétel a települési programokon, civil akciókban, esetleg a település lakossága számára is nyitott programok 
szervezése. Ez utóbbi integrációs funkció - bár vannak egyedi esetek - a lakópark zártságának függvényében változik. Minél nyitottabb egy lakópark, annál inkább nyit a lakossági szervezet tevékenysége is az adott település egésze felé. Míg a zárt és az inkább zárt lakóparkok esetében ez nem kifejezetten jellemző, inkább csak a szükséges jó kapcsolat megtartására irányul (ha van jó kapcsolat), addig a közepesen zárt lakóparkok már deklaráltan gondot fordítanak arra, hogy jó kapcsolatot ápoljanak a települési önkormányzattal, és részt vegyenek a település életében. Ugyanakkor a lakópark elkülönülése, a saját lakóparki identitás megtartása ugyanilyen jelentőségű, belső közösségük sokkal erősebb, mint a zárt lakóparkoké.

„Alapjáraton, én úgy gondolom, a célcsoportunk az mi vagyunk. (...) [Az egyik programon] voltak mások is, és a közösség érezte, hogy ez sok." (egyesület 2, elnökségi tag)

Az inkább nyillt és a nyílt lakóparkok szervezetei ezzel szemben tevékenységüket az egész településre kifejtik, közösségi programjaik a település minden lakosának szólnak, inkább csak fejlesztéseik koncentrálódnak a lakópark területére.

„Segit az önkormányzat abban, hogy átveszik fenntartásra, amit csinálunk, de mondjuk mi is részt veszünk minden évben a felújitásokban, javitásokban. Minden rendezvény (gyereknap, Liget fesztivál), mindegyiknek az a célja, hogy az emberek barátkozzanak. Ezeknek a rendezvényeknek a célja a közösségépités, az adománygyüjtés, de támogatunk a bevételböl másokat is, például a polgárörséget a falun belül. Ezek nyitott rendezvények, jönnek a faluból, de környező településekröl is." (egyesület 6, elnök)

Természetesen a kapcsolatok minősége az adott önkormányzatok hozzáállásán is múlik:

„... nem érdekli az önkormányzatot a lakóparkok helyzete (...) pont emiatt akart (...) leválni. De ök speciális helyzetben voltak, mert az akkori polgármester állandóan öket szívatta." (lakóparki lakó)

„Vegyesek a kapcsolatok, mostanában nyitottabbak, ha kezdeményezünk valamit, jobban segitenek, kérnek véleményt." (egyesület 2, elnökségi tag)

„Nagyon együttmüködik az önkormányzat, támogatnak minket.” (egyesület 6, elnök)

1. táblázat. A különböző lakópark-típusokban müködő, vizsgált lakóparki szervezetek jellemzői

\begin{tabular}{|c|c|c|c|c|c|}
\hline Lakópark típus & $\begin{array}{c}\text { Vizsgált szerve- } \\
\text { zetek száma }\end{array}$ & $\begin{array}{l}\text { Alapítás fő } \\
\text { motivációja }\end{array}$ & $\begin{array}{c}\text { Jellemző } \\
\text { szervezettípus }\end{array}$ & $\begin{array}{l}\text { Jelenlegi domi- } \\
\text { náns funkció }\end{array}$ & $\begin{array}{c}\text { Települési } \\
\text { kapcsolatok }\end{array}$ \\
\hline Zárt & 4 & önigazgatás & $\begin{array}{c}\text { nonprofit kft. + } \\
\text { egyesület }\end{array}$ & önigazgatás & gyenge \\
\hline Inkább zárt & 2 & önigazgatás & egyesület & önigazgatás & gyenge \\
\hline Közepesen zárt & 5 & érdeksérelem & egyesület & $\begin{array}{l}\text { területfejlesztés + } \\
\text { közösségépítés }\end{array}$ & $\begin{array}{l}\text { együttműködő, } \\
\text { de távolságtartó }\end{array}$ \\
\hline Inkább nyílt & 3 & $\begin{array}{l}\text { érdeksérelem + } \\
\text { közösségépítés }\end{array}$ & egyesület & $\begin{array}{l}\text { közösségépítés + } \\
\text { területfejlesztés }\end{array}$ & élénk \\
\hline Nyílt & 3 & $\begin{array}{l}\text { közösségépítés + } \\
\text { területfejlesztés }\end{array}$ & egyesület & közösségépítés & élénk \\
\hline
\end{tabular}




\section{KÖVETKEZTETÉSEK}

Mindezen eredmények azt mutatják, hogy a lakóparkok a társadalmi tóke koncentrálódásának potenciális helyszínei. A lakók közötti erős hálózati tőke így jelentős erőforrást biztosíthat közös ügyeik intézéséhez, szervezetük múködtetéséhez. Ezt jól mutatja számos, a kvalitativ adatfelvétel során hallott példa: míg általában a civil szervezetek küzdenek azzal, hogy megfelelő szakmai hátterük legyen, fizetnek könyvelőt, informatikust, jogászt, addig a legtöbb lakóparki szervezetben a lakók között akadnak ilyen szakemberek, akik önkéntes munkában vállalják ezeket a feladatokat. Viszonylag könnyen találnak szponzorokat is. Ha ezt csupán saját javukra fordítják, akkor az összetartó („,bonding”) típusú társadalmi tőke dominál, de ha az összekötő („bridging”) típusú társadalmi tőke is magas, ugyanígy erőforrást jelenthetnek a tágabb társadalmi közeg számára is, ahogy azt több település esetén tapasztaltam. Ez azonban függ a társadalmi környezet viselkedésétől is. A lakóparki szervezetek léte azonban mindenképpen lehetőség a legtöbb esetben szegregáltan élő lakóparki lakók települési kapcsolatainak, vagyis az összekötő („,bridging”) típusú társadalmi tőke fejlesztésére. Habár különböző mértékben, de minden általam vizsgált civil szervezet kapcsolódási lehetőséget jelentett a lakópark és az anyatelepülés között. A lakók megszólítása, települési ügyekbe való bevonása általuk sokkal egyszerúbbnek látszott, mint azokban a lakóparkokban, ahol a lakók nem rendelkeztek közösségi szervezettel. Ez az önkormányzatok képviselőivel készült interjúkban visszatérően elhangzott.

„.... az egyesület az érdeklődést mutat, velük van jó kapcsolat” (polgármester 1)

„... ezekben a szervezetekben nagyon nagy tenni akarás van, amit tudunk a közösségeink fejlesztésére használni." (polgármester 2)

Ugyanakkor kritikus vélemény is elhangzott:

„[A lakóparkban] élók rendezik ott a saját életüket, abba az önkormányzatnak nem sok beleszólása van. Annyi, hogy ha valami szabályozás van, akkor ök véleményezhetik a dolgokat. És sokszor nem a teljes közösség érdekeit jelenítik meg, hanem egy-egy szószólóét." (önkormányzat 3)

Mindez azt mutatja, hogy a lakóparkok nem feltétlenül a negatív, „összeköto”" társadalmi tőke mintapéldái. Ahogy láttuk, a kép nálunk ennél sokkal árnyaltabb, és attól függ, hogy a közösségen kívüli kapcsolatok milyen jellegúek.

A hálózati tőke létrejötte, illetve erőssége, intézményesültsége sem magától értetődő, hiszen ahogy láttuk, a budapesti agglomeráció lakóparkjai között viszonylag kevés esetben találkozhatunk a közösségi összefogás jeleivel, és szúk azon lakóparkok csoportja, ahol bejegyzett társadalmi szervezet múködik. Az eredmények azt is megmutatták, hogy ezen utóbbi esetekben is lényeges különbségek figyelhetők meg a lakóparkok között, mely különbségek az egyéni jellemzőkön túl szorosan kapcsolódnak az adott lakópark típusához. Habár mind az öt lakóparki típus képviselői arról számoltak be, hogy alapvetően nehéz a lakók aktivizálása, leginkább csak személyes érintettség mentén szervezhető a lakosság, mégis a társadalmi tőke szerepe a közepesen zárt, inkább nyílt és teljesen nyílt lakóparkok esetében eltér a zárt és inkább zárt lakóparkokban tapasztaltaktól. Összetartó („,bonding”) és összekötő („,bridging”) típusú társadalmi tőkéjük egyaránt sokkal erősebb, mint a zárt lakóparkoknak. Ennek oka, hogy létük is magához a lakóparkban létrejövő hálózati tőkéhez köthető. Míg a zárt lakóparkok esetében a kezdettől fogva meglévő közös javak indokolják a szervezet alapítást, addig ezekben a típusú 
lakóparkokban nincs eleve szükség ilyen szerveződésekre. Ahol mégis létrejön a civil szervezet, ott mindenhol volt valami kiváltó ok, ami közös cselekvést tett szükségessé. Az ismétlődő kooperációs helyzetek erősítették a lakók közti kapcsolatokat, ami megteremtette az alapot az így létrejövő hálózati tőke intézményesüléséhez, vagyis a szervezetalapításhoz. Miután a kezdeti, többnyire érdekvédelmi vagy lakóparkfejlesztési céljaikat elérték, a szervezetek vagy elhaltak (korábbi vizsgálatomban erre is akadt példa), vagy az idő előrehaladtával egyre inkább a közösségépítési feladataik váltak dominánssá. Így Coleman nyomán tulajdonképpen „kisajátítható” társadalmi szervezetekként viselkednek, melyek a közösségépítő funkció révén fenntartják és növelik a lakóközösségben a korábbi közös ügy révén létrejött hálózati kapcsolatokat.

Lin (2001a: 193) azt mondja, hogy „a társadalomba beágyazott erőforrások akkor válnak társadalmi tőkévé, amikor valaki kapcsolatainak egy láncát aktivizálja, mobilizálja egy meghatározott cél elérése érdekében, például állásszerzés céljából". Ugyanígy, amikor a lakóparki civil szervezetek felhasználják a lakók közti hálózati tőkét, akkor válik az számukra valódi társadalmi tőkévé, mely lehetővé teszi újabb javak és közös cselekvések megvalósítását, jelentősen növelve az adott lakópark életminőségét. Habár az egyes lakók eltérő mértékben vesznek részt ebben, az így létrejövő javak mégis klubjavaknak tekinthetőek, hiszen olyan helyi közjószágok, melyek a klub, jelen esetben a lakópark minden lakója számára elérhetővé válnak. Például a rendszeres közös szemétszedés, virágosítás, fejlesztés (játszótér, focipálya, padok stb.), egymásra figyelés eredménye tisztább, szebb, felszereltebb és biztonságosabb lakókörnyezet.

\section{ÖSSZEGZÉS}

Az írásom elején feltett három kérdésre a következő válaszok adhatók.

A fentebb ismertetett adatok, valamint kvalitatív és kvantitatív adatgyújtésem alapján úgy gondolom, hogy a lakóparkok a társadalmi tőke koncentrációjának potenciális helyszínei. Az itt élők a Bourdieu által leírt különböző tőketípusok közül magas anyagi és kulturális tőkével rendelkeznek, melyet kutatásom szerint feltételezhetően magas társadalmi tôke egészít ki. Ez utóbbi állítást azonban célzottabb kvantitatív adatgyűjtés tudná alátámasztani.

Általánosságban a budapesti agglomeráció lakóparkjaira vonatkozóan kutatásom eredményei azt mutatják, hogy a budapesti agglomeráció lakóparknak nevezett ingatlancsoportjaiban a szomszédsági kapcsolatok többnyire minimálisak, illetve nem térnek el egy átlagos (városi) szomszédság esetén tapasztaltaktól. Az itt élók egyéni társadalmi tőkéje csak lazán kapcsolódik a lakóhelyükhöz, melynek okai közt szerepelhet a (felső) középosztályhoz tartozó lakók életmódja: az elfoglaltság, az ingázó életmód, valamint a Coleman által említett jómód, mely csökkenti a szomszédok egymásrautaltságát. Interjús beszámolók szerint is a lakók többsége szinte csak aludni jár haza. Kapcsolataik leginkább a gyermekeik révén alakulnak ki, hiszen jellemzően az otthon lévő kisgyermekes anyáknak van legtöbb kapcsolata a szomszédságban, és a tágabb település lakóit is leginkább az óvodában, iskolában van lehetőség megismerni. Lakóparkon kívüli kapcsolataikat, az adott település életébe való bekapcsolódásukat mindezek mellett csökkenti a lakóparki építkezések jellege, mely a településre érkező új lakócsoportok egy tömbben való elhelyezkedését okozza. Zárt lakóparkok esetében a közös javakhoz fúződő érdekek tovább erősíthetik az összetartó („,bonding”) típusú hálózati tőke kialakulását. 
Ugyanakkor azokban a közepesen zárt, inkább nyílt és nyílt lakóparkokban, ahol civil szervezetek múködnek (illetve bizonyos mértékig a zárt lakóparkok egyesületeiben is), némileg más a helyzet. Ezeket a szervezeteket eleve a társadalmi tőke jelenléte, a hálózatosodás hozta létre, mely a közös ügy során „ismétlődő kooperációs helyzetek” (Fukuyama 2000: 13-14) eredményeképpen alakult ki. Az összetartó („,bonding”) jellegú hálózati tőkét közösségépítő funkciójuk erősíti, ugyanakkor a zárt-nyílt lakópark-skálán a nyíltság mértékének növekedésével nő az összekötő („,bridging”) típusú kapcsolatok jelenléte is. Ez utóbbi, a tágabb társadalmi környezettel összekötő kapcsolatok kialakításában ezek a szervezetek szintén úttörő szerepet vállalnak. Természetesen az erre vonatkozó eredményeim még korántsem teljes körűek, de rávilágítanak arra, hogy a lakóparkokról kialakult, hazai szakirodalomban is tapasztalható, sokszor egysíkú képet érdemes árnyalni, illetve társadalmi tőke kapcsán célzottabban is kutatni.

A társadalmi tőke és a lakóparki civil szervezetek kapcsolatára vonatkozó harmadik kutatási kérdésemmel kapcsolatban a társadalmi tőke és a klubjavak elmélete adta elméleti keretben értelmezve a következő „folyamat" írható le. A lakóparkokban adott egy nagyjából homogén társadalmi közeg, amelyet a lakóhely kapcsán nagyjából homogén egyéni és közösségi érdekek jellemeznek, mégpedig a helyi közjavak létrehozása és védelme, melyeket mint klubjavakat állítanak elő. Ennek kapcsán az ott élők ismétlődő kooperációs helyzetekbe kerülnek, melyek intenzitását fokozza, ha hirtelen szembesülnek valamilyen nagyobb közös problémával, érdeksérelemmel. Ha van egy kiváltó tényező, akkor szervezetet alapítanak, mely Bourdieu nyomán tekinthető társadalmi tókéjük intézményesítésének. Ha elmúlt a „veszély”, megoldódott a kiváltó probléma, akkor is érdemes fenntartaniuk ezt az intézményt, mint egyfajta „kisajátítható társadalmi szervezetet” (Coleman 1998), hiszen a tapasztalat azt mutatja, hogy az továbbra is hasznos a közösség számára. Ha jól mozgósítható az így létrejött társadalmi tőke, vagyis jól működik a szervezet, akkor a létrehozott klubjavak köre közös erővel hatékonyabban bővíthető, fejleszthető és megvédhető. Ez pedig az átkonvertálhatóság útján már az egyének gazdasági tőkéjét is növeli, mivel szinten tartja, vagy akár emeli az lakók ingatlanjainak értékét is. A szervezet ekkor már nem csak materiális klubjavak előállítására alkalmas, hanem bizonyos értelemben klubjószággá teszi magát a társadalmi tőkét is, a közösségépítő funkció felvállalásával újra is termeli azt. ${ }^{13}$

13 A társadalmi tőke klubjószágként való értelmezése megjelenik külföldi és hazai írásokban is. Hilber (2015) tanulmányában a lakásárak alakulása és a tulajdonosi viselkedéssel kapcsolatban értelmezi klubjószágként a társadalmi tőkét, mint olyan helyi közjószágot, melyre a tulajdonosok a bérlőkhöz képest sokkal több időt és energiát áldoznak. Galbraith, Rodrigues és Stiles (2007) pedig az etnikai alapú közösségek vizsgálatában a klubelmélet alkalmazásával próbálja megragadni azokat az előnyöket, amely a csoporthoz tartozással jár. Szerintük a társadalmi tőke a legfontosabb olyan klubjószág, melyet ezek az etnikai közösségek tagjaik számára nyújtani tudnak.

A hazai szerzők közül Bodor Ákos (2013) a területi tőkével kapcsolatban említi a társadalmi tőke klubjószágként való értelmezését. Savanya Péter szerint pedig a klubok esetében a hálózatok tagsága zárt, így jól körülhatárolható, hogy ki férhet hozzá a hálózat által biztosított erőforráshoz (Savanya 2013: 146), mely ilyen módon a közösség klubjószága (Savanya 2013: 144). 


\begin{tabular}{|c|c|c|c|c|c|c|c|c|c|}
\hline 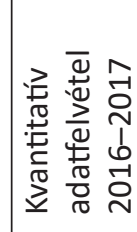 & 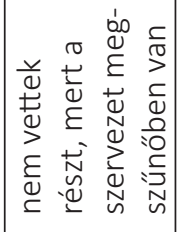 & $\begin{array}{l}\frac{0}{0} \\
\frac{0}{N} \\
N \\
\frac{\pi}{10} \\
\infty \\
\infty\end{array}$ & 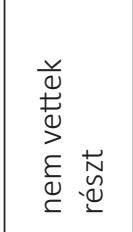 & 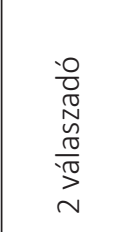 & 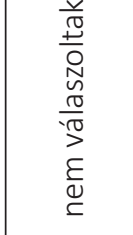 & 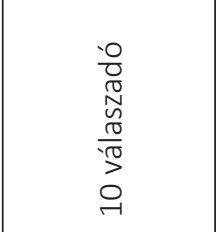 & $\begin{array}{l}\frac{0}{0} \\
\frac{\pi}{N} \\
N \\
\frac{\pi}{-10} \\
D \\
m\end{array}$ & 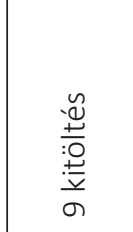 & 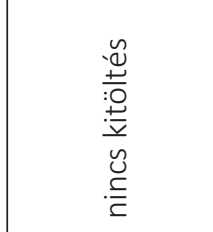 \\
\hline 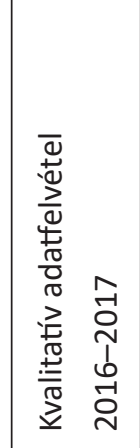 & 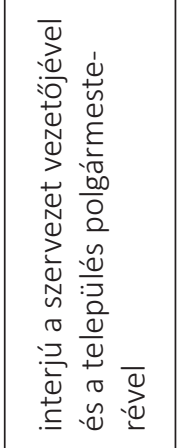 & 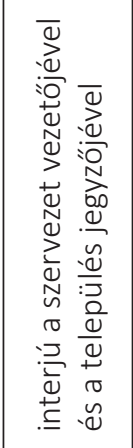 & 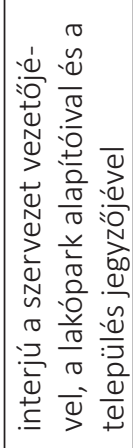 & 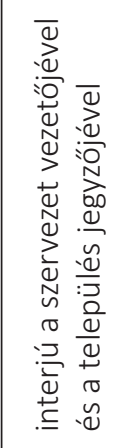 & 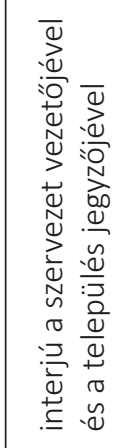 & 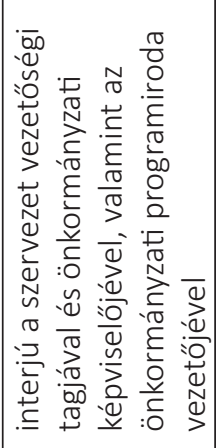 & 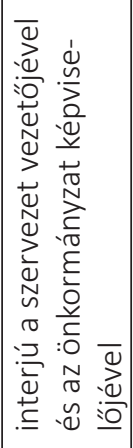 & 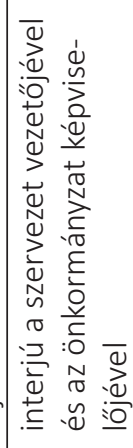 &  \\
\hline 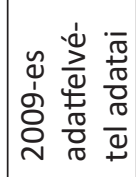 &  & 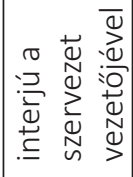 &  &  &  &  &  &  & 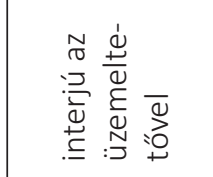 \\
\hline  &  &  &  &  &  &  &  &  &  \\
\hline 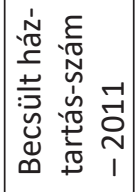 &  & 8 & $\stackrel{\llcorner}{\emptyset}$ & $\wedge$ & $\stackrel{\widetilde{\sigma}}{\check{S}}$ & 극 & 岕 & $\stackrel{\sim}{\forall}$ & $\underset{\sim}{\stackrel{\infty}{\sim}}$ \\
\hline$\stackrel{\mathbb{N}}{\mathbb{N}}_{0}^{+}$ & 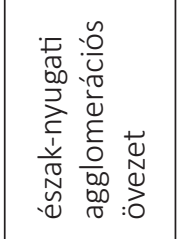 & 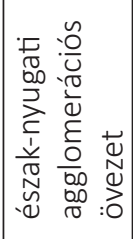 & 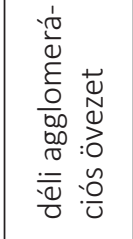 & 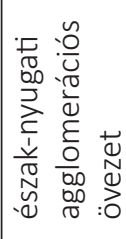 &  & 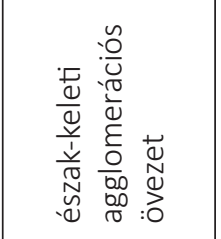 & 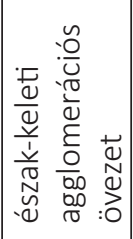 & & 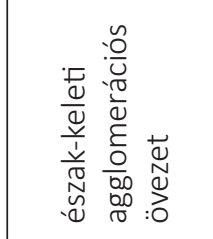 \\
\hline$\stackrel{n}{\stackrel{n}{a}}$ & 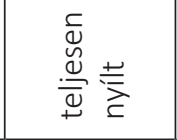 &  & 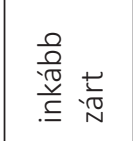 & 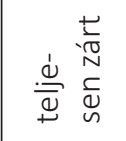 & 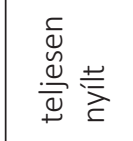 & 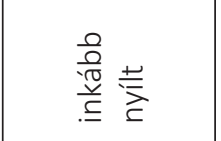 & 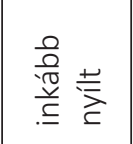 & 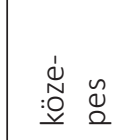 & 离 \\
\hline 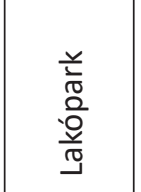 & 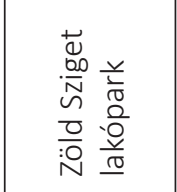 & 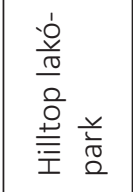 & 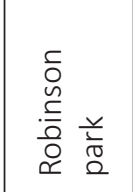 & 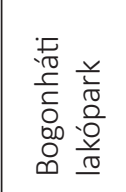 & 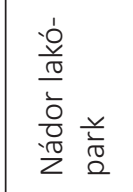 & 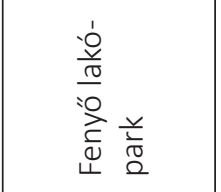 & 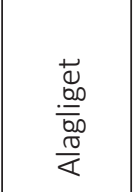 & 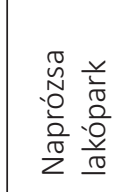 &  \\
\hline$\frac{\frac{\mathscr{q}}{0}}{\frac{\partial}{0}}$ &  & $\begin{array}{l}: 0 \\
\frac{0}{0} \\
\frac{0}{\pi} \\
\frac{0}{0} \\
0 \\
0\end{array}$ & $\begin{array}{l}\frac{N}{N} \\
\frac{N}{0} \\
\frac{\widehat{D}}{00} \\
\frac{0}{0} \\
\frac{0}{0}\end{array}$ & 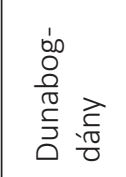 & 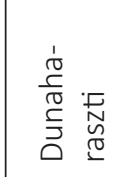 & $\begin{array}{l}\bar{N} \\
\frac{\tilde{Q}}{\sqrt{0}} \\
\stackrel{5}{\bar{V}} \\
0\end{array}$ & 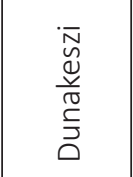 & 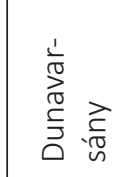 & $\psi$ \\
\hline
\end{tabular}




\begin{tabular}{|c|c|c|c|c|c|c|c|c|}
\hline 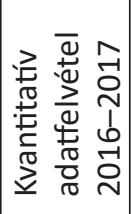 & 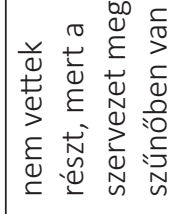 & 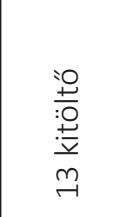 & $\begin{array}{l}\frac{0}{0} \\
\frac{0}{0} \\
: \frac{0}{i} \\
m\end{array}$ & 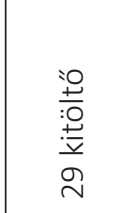 & $\begin{array}{l}\frac{0}{0} \\
\frac{10}{0} \\
\frac{7}{5} \\
0\end{array}$ & 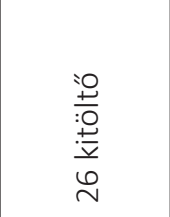 & 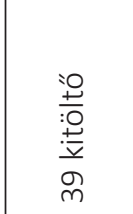 & 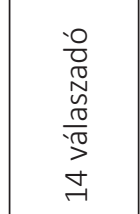 \\
\hline 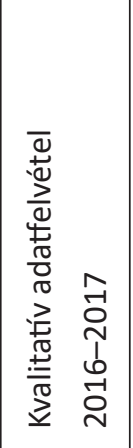 & 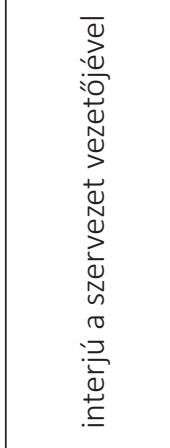 & 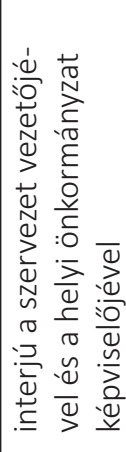 & 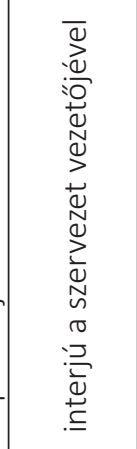 & 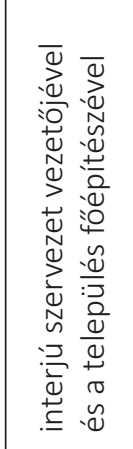 & 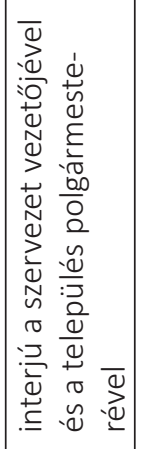 & 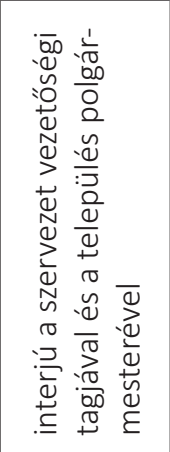 & 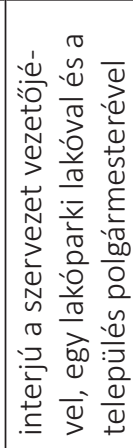 & 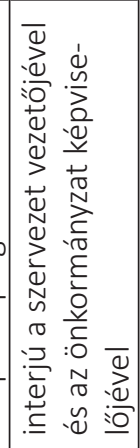 \\
\hline 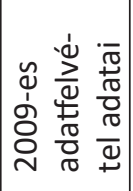 & 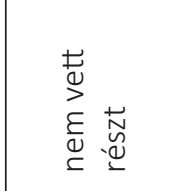 & 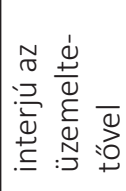 & 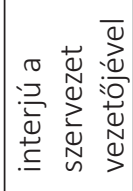 & 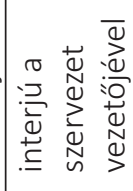 & 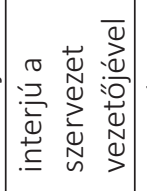 & 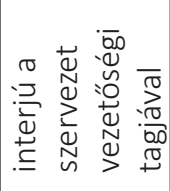 & 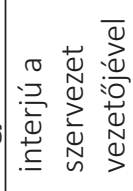 & 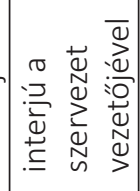 \\
\hline 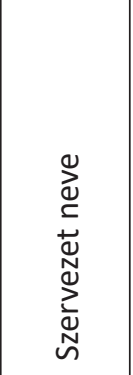 & 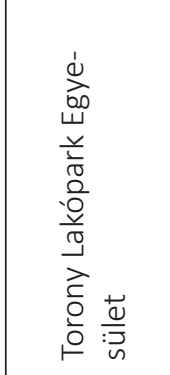 & 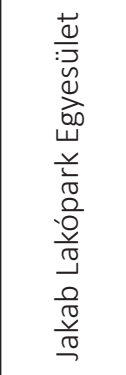 & 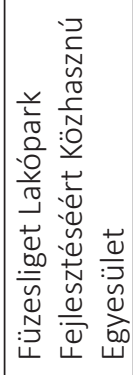 & 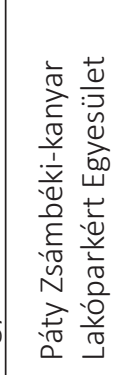 & 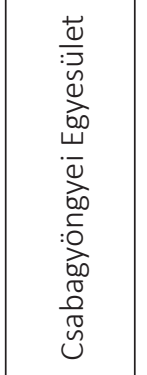 & 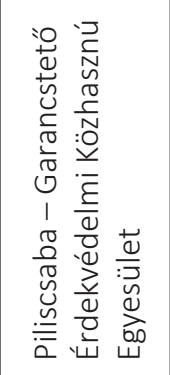 & 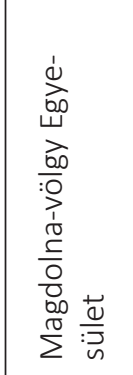 & 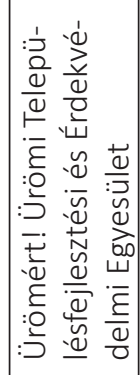 \\
\hline 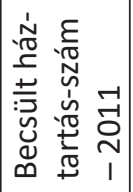 & $\stackrel{\text { வ் }}{\check{\Sigma}}$ & $\stackrel{\infty}{\infty}$ & $\underset{\sim}{\stackrel{f}{F}}$ & 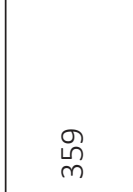 & $\stackrel{\bullet}{\sim}$ & & $\rightarrow$ & જૂ \\
\hline$\stackrel{D}{N}_{0}^{+}$ & 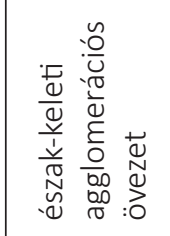 & 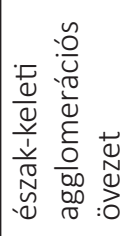 & 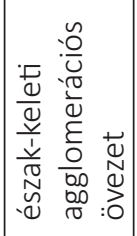 & 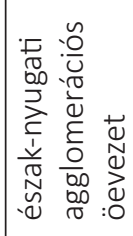 & 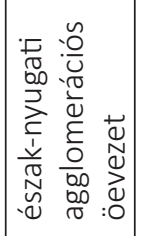 & 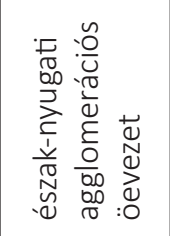 & 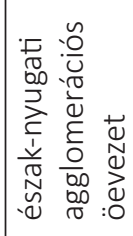 & 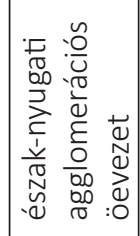 \\
\hline$\stackrel{n}{a}$ & 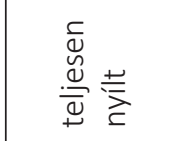 & 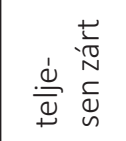 & 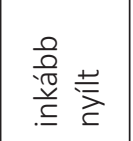 & 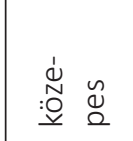 & 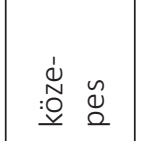 & 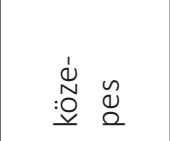 & & 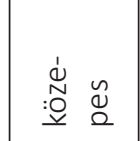 \\
\hline 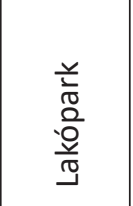 & 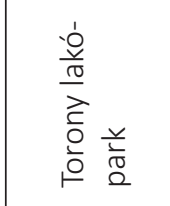 & 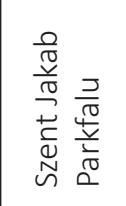 & 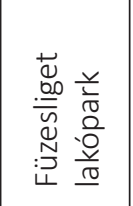 & 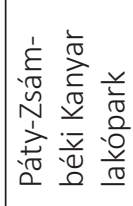 & 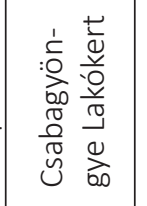 & 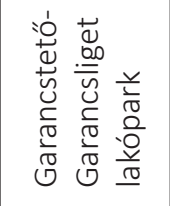 & 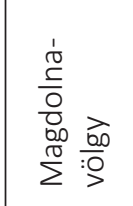 & 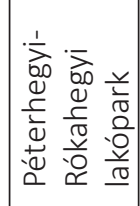 \\
\hline$\frac{\frac{\mathscr{d}}{0}}{\frac{0}{0}}$ & 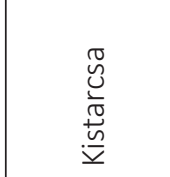 & $\begin{array}{l}\overline{0} \\
\frac{0}{0} \\
00 \\
00 \\
\sum^{0}\end{array}$ & 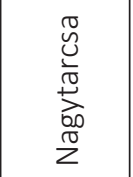 & $\pi$ & 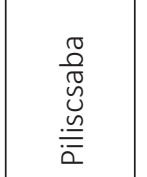 & 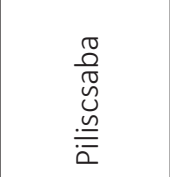 & $\begin{array}{l}\frac{\pi}{0} \\
\stackrel{0}{0} \\
\stackrel{.}{=} \\
\overline{\bar{a}}\end{array}$ & $\begin{array}{l}\text { है } \\
: \stackrel{0}{0}\end{array}$ \\
\hline
\end{tabular}




\section{HIVATKOZÁSOK}

Angelusz R. (2010) Tőke vagy erőforrás? Adalékok a társadalmi tőke elméletéhez. Szociológiai Szemle, 20(3): 147-166.

Atkinson, Robert - Blandy, Sarah (2005) Introduction: International Perspectives on The New Enclavism and the Rise of Gated Communities. Housing Studies, 20/2, 177-186. https://doi.org/10.1080/0267303042000331718

Bajmóczy P. (2014) A szuburbanizáció két évtizede Magyarországon. Észak-magyarországi Stratégiai Füzetek, 2, 6-17.

Bartal, A. M. (2005) Nonprofit elméletek, modellek, trendek. Budapest: Századvég Kiadó.

Bodor Á. (2013) A társadalmi tőke szerepe a területi tőke kutatásában. In Rechnitzer J. - Somlyódyné Pfeil E. - Kovács G. (szerk.) A hely szelleme - a területi fejlesztések lokális dimenziói: A Fiatal Regionalisták VIII. Konferenciáján elhangzott előadások. Győr: Széchenyi István Egyetem Regionális és Gazdaságtudományi Doktori Iskola, 2013, 39-46.

Buchanan, J. M. (1965) An Economic theory of clubs. Economia, 32/125, 1-14. https://doi.org/10.2307/2552442

Bourdieu, P. (1998) Gazdasági tőke, kulturális tőke, társadalmi tőke, In Lengyel Gy. - Szántó Z. (szerk., 1998) Tőkefajták: A társadalmi és kulturális erőforrások szociológiája. Aula Kiadó.

Coleman, J. S. 1994 Társadalmi tőke. In Lengyel Gy. - Szántó Z. (szerk.) A gazdasági élet szociológiája. Budapest: AULA Kiadó.

Coleman, J. S. (1998) A társadalmi tőke az emberi tőke termelésében. In Lengyel Gy. - Szántó Z. (szerk.) Tőkefajták: A társadalmi és kulturális erőforrások szociológiája. Budapest, 1998, AULA Kiadó.

Cséfalvay Z. (2008) Kapuk, falak, sorompók. A lakóparkok világa. Budapest: Gondolat-Marina Part.

Csizmadia Z. (2004) Társadalmi kapcsolatok - struktúra - rétegződés: a szerkezet és az egyenlőtlenség kérdése a társadalmi tőkeelméletekben. In Némedi D. - Szabari V. (szerk.) Kötö-Jelek. Budapest: ELTE Szociológiai Doktori Iskola, 119-145.

Csizmadia Z. (2008) Kapcsolathálózatok és társadalmi ,tőkék'. A társadalmi viszonyok felértékelődése a szociológia legújabb szakaszában. In Némedi D. (szerk.) Modern szociológiai paradigmák. Budapest: Napvilág Kiadó.

Debertin, D. L. - Goetz, S. J. (2013) Social Capital Formation in Rural, Urban and Suburban Communities. University of Kentucky, Staff Paper 474.

Esser, H. (2008) The two Meanings of Social Capital. In Castiglione, D. - Van Deth, J. W. - Wolleb, G. (eds.) The Handbook of Social Capital. Oxford: Oxford University Press, 22-49.

Fukuyama, F. (2000) A nagy szétbomlás. Az emberi természet és a társadalmi rend újjátervezése. Budapest: Európa Könyvkiadó

Galbraith, C. S. - Rodriguez, C. L. - Stiles, C. H. (2007) Social capital as a club good: the case of ethnic communities and entrepreneurship. Journal of Enterprising Communities: People and Places in the Global Economy, 1/1, 38-53. https://doi.org/10.1108/17506200710736258

Glasze, G. (2005) Some Reflections on the Economic and Political Organisation of Private Neighbourhoods. Housing Studies, 20/2, 221-233. https://doi.org/10.1080/026730303042000331745

Granovetter, M. (1973) The Strength of Weak Ties. American Journal of Sociology, 78,6, 1360-1380. https://doi.org/10.1086/225469

Granovetter, M. (1975) Getting a Job: A Study of Contacts and Careers. Contemporary Sociology, 4, 3, 264. https://doi.org/10.2307/2063210

Granovetter, M. (1988) A gyenge kötések ereje. A hálózatelemzés felülvizsgálata. In Angelusz R. - Tardos R. (szerk.) Válogatás a kapcsolathálózati elemzés irodalmából. Szociológiai Figyelő.

Galbraith, C. S. - Rodriguez, C. L. - Stiles, C. H. (2007) Social capital as a club good: the case of ethnic communities and entrepreneurship. Journal of Enterprising Communities: People and Places in the Global Economy, Vol. 1 Issue 1, 38-53. https://doi.org/10.1108/17506200710736258

Hajdu G. - Megyesi B. (2017) Társadalmi tőke és társadalmi integráció. In Kovách Imre (szerk.) Társadalmi integráció, Az egyenlötlenségek, az együttmüködés, az újraelosztás és a hatalom szerkezete a magyar társadalomban. MTA Társadalomtudományi Kutatóközpont Szociológia Intézet, Budapest - Belvedere Meridionale Kiadó, 155-181.

Hanifan, L. J. (1916) The Rural School Community Center. Annals of the American Academy of Political and Social Science 67. https://doi.org/10.1177/000271621606700118

Hanifan, L. J. (1920) The Community Center. Boston: Silver Burdett

Hegedűs G. (2007) A lakóparkokban élők és környezetük szociálgeográfiai kapcsolatai. In Orosz Z. - Fazekas I. (szerk.) Települési környezet. A 2007. november 8-10-én a Debreceni Egyetem Tájvédelmi és Környezetföldrajzi Tanszéke szervezésében megrendezett Települési Környezet Konferencia előadásai, 299 p.

Hilber, C. A. L. (2015) The Economic Implications of House Price Capitalization: A Synthesis. Real Estate Economics, 45, 2, $301-339$. https://doi.org/10.1111/1540-6229.12129 
Hobbes, G. (2000) What is social capital? A brief literature overview. www. caledonia.org.uk/hobbs.pdf (2017. 12. 01.) https://doi.org/10.1002/0470020784.ch1

Jacobs, J. (1961) The Death and Life of Great American Cities. New York: Random.

Kisfalusi D. (2013) Kapcsolati és hálózati tőke. Vázlat a társadalmi tőke kettős természetről. Szociológiai Szemle, 23(3): 84-101.

Koltay E. (2010) Lakóparki civil/nonprofit szervezetek a budapesti agglomerációban. Szakdolgozat. PPKE BTK Szociológia Intézet, Piliscsaba.

Kozel, V. - Parker, B. (1998) Poverty in Rural India: The Contribution of Qualitative Research in Poverty Analysis. Washington, The World Bank.

KSH (2007) Lakásstatisztikai Évkönyv. Melléklet: Módszertan. KSH, Budapest.

KSH (2013) 2011. évi Népszámlálás. Területi adatok, Pest megye. http://www.ksh.hu/docs/hun/xftp/idoszaki/nepsz2011/ nepsz_03_14_2011.pdf (letöltés: 2017. 10.16.)

KSH (2016) Statisztikai Tükör, Népmozgalom 2016 (megjelent: 2017. április 21.).

Lang, R. E. - Danielson, K. A. (1997) Gated Communities in America: Walling out he world? Housing Policy Debate, 8(4): $867-899$. https://doi.org/10.1080/10511482.1997.9521281

Laury, G. (1977) A Dynamic Theory of Racial Income Differences. In Wallace, P. A. - LeMund, A. (eds.) Women, Minorities, and Employment Discrimination. Massachusetts: Lexington Books,1977: Chapter 8.

Lin, N. (2008) A network Theory of Social Capital. In Castiglione, D. - Van Deth, J. W. - Wolleb G. (ed.) The Handbook of Social Capital. Oxford University Press.

Lin, N. - Ensel, W. - Vaughn, J. C. (1981) Social Resources and Strength of Ties: Structural Factors in Occupational Status Attainment. American Sociological Review, 46(4): 393-405. https://doi.org/10.2307/2095260

Lin, N. (2001a) Building a Network Teory of Social Capital. In Lin, N. - Cook, K. - Burt, R. S. (eds.) Social Capital: Theory and Research. New York: Aldine de Gruyter, 3-29.

Lin, N. (2001b) Social Capital: A Theory of Social Structure and Action. Cambridge: Cambridge University Press.

Lin, N. - Cook, K. - Burt, R. S. (eds.) (2001) Social Capital: Theory and Research. New York: Aldine de Gruyter.

Low, S. M. (2003) Behind the Gates: Life, Security, and the Pursuit of Happiness in Fortress America. New York: Routledge. https://doi.org/10.4324/9780203491256

Manski, C. F. (2000) Economic Analysis of Social Interactions. Journal of Economic Perspectives, 14(3), 115-136. https://doi.org/10.1257/jep.14.3.115

McKenzie, E. (2003) Common interest housing in the communities of tomorrow,Security versus Status? Housing Policy Debate, 14 (1/2), 203-234. https://doi.org/10.1080/10511482.2003.9521473

Megyesi B. (2015) A társadalmi tőke negatív hatásai. Századvég, 78.

Orbán A. - Szántó Z. (2005) Társadalmi tőke. Erdélyi Társadalom, 2005/2, 55-70.

Perpék É. (2011) Önkéntesség és közösségfejlesztés. Ph.D. értekezés, Budapesti Corvinus Egyetem, Szociológia Doktori program. https://doi.org/10.14267/phd.2013011

Portes, A. (1998) Social Capital: Its Origins and Applications in Modern Sociology. Annual Review of Sociology, 24(1): 1-24. https://doi.org/10.1146/annurev.soc.24.1.1

Portes, A. (2010) Economic Sociology: A Systematic Inquiry. Princeton, NJ: Princeton University Press. https://doi.org/10.5860/choice.48-1783

Putnam, R. D. (1993) Making Democracy Work: Civil Tradition in Modern Italy. Princeton, Princeton University Press. https://doi.org/10.2307/2151707

Putnam, R. D. (2000) Bowling Alone. The Collapse and revival of American community. New York: Simon and Schuster. https://doi.org/10.5860/choice.38-2454

Putnam, R. D. (ed.) (2002) Democracies in Flux: The Evolution of Social Capital in Contemporary Societies. New York: Oxford University Press.

Ruef, M. - Kwon, S. (2016) Neighborhood Associations and Social Capital. Social Forces, 95(1), 159-189. Oxford University Press https://doi.org/10.1093/sf/sow053

Savanya P. (2013) A társadalmi tőke jelentősége a gazdaságban, szerepe az innovációk társadalmi megformálásában. In Bajmóczy Z. Elekes Z. (szerk.) Innováció: a vállalati stratégiától a társadalmi stratégiáig. JATEPress, Szeged, 140-159. 
Sanchez, T. W. - Lang, R. E. - Dhavale, D. M. (2005) Security versus Status? A First Look at the Census's Gated Community Data. Journal of Planning Education and Research Association of Collegiate Schools of Planning, 24: 281-291.

Schuchmann J. (2015) Költözési szándék és lakóhelyi szuburbanizáció a budapesti agglomerációban. In. Hervainé Sz. Gy. (szerk.) A 21. századi államiság kérdőjelei. Kodolányi János Főiskola, Székesfehérvár, 319-334.

Sik E. (2006) Tőke-e a kapcsolati tőke, s ha igen, mennyiben nem? Szociológiai Szemle, 16(2): 72-95.

Sik E. (2012) A kapcsolati tőke szociológiája. Budapest: ELTE TÁTK

Sobel, J. (2002) Can We Trust Social Capital? Journal of Economic Literature, XL: 139-154. https://doi.org/10.1257/jel.40.1.139

Szreter, S. - Woolcock, M. (2004) Health by association? Social capital, social theory, and the political economy of public health. International Journal of Epidemiology, 33, 650-667. https://doi.org/10.1093/ije/dyh013

Wilson, P. A. (1997) Building Social Capital: A Learning Agenda for the Twenty-first Century. Urban Studies, 34(5-6): 745-760. https://doi.org/10.1080/0042098975808

Woolcock, M. (1998) Social capital and economic development: Toward a theoretical synthesis and policy framework. Theory and Society, 27, 151-208. http://dx.doi.org/10.1023/A:1006884930135

Woolcock, M. - Narayan, D. (2000) Social Capital: Implications for Development Teory, Research, and Policy. Te World Bank Research Observer, 15/2, 225-249. https://doi.org/10.1093/wbro/15.2.225 